\title{
The Community Food Centre: Creating space for a just, sustainable, and healthy food system
}

\author{
Charles Z. Levkoe, ${ }^{\mathrm{a}}$ University of Toronto, and Sarah Wakefield, ${ }^{\mathrm{b}}$ University of Toronto
}

Submitted 10 December 2010 / Major revision 29 August 2011 / Accepted 2 September 2011 /

Published online 21 November 2011

Citation: Levkoe, C. Z., \& Wakefield, S. (2011).The Community Food Centre: Creating space for a just, sustainable, and

healthy food system . Journal of Agriculture, Food Systems, and Community Development. Advance online publication.

http://dx.doi.org/10.5304/jafscd.2011.021.012

Copyright (C) 2011 by New Leaf Associates, Inc.

\begin{abstract}
Alternative food initiatives have been challenged by critics to address the long-term, structural challenges confronting the food system in an integrated and comprehensive way. Confronting these
\end{abstract}

a Corresponding author: $\mathrm{PhD}$ candidate, University of Toronto, Department of Geography and Program in Planning, University of Toronto, 100 St. George Street, Toronto, Ontario M5S 3G3 Canada; charles.levkoe@utoronto.ca

b Associate Professor, University of Toronto, Department of and Program in Planning, University of Toronto, 100

St. George Street, Toronto, Ontario M5S 3G3 Canada; sarah.wakefield@,utoronto.ca

Disclosures

Financial support for the initial research and original report was provided by the Metcalf Foundation in the form of a grant to The Stop Community Food Centre as part of the Food Solutions working paper series (http://www.metcalffoundation. org). The lead author was employed by The Stop CFC as the primary researcher and co-writer for the original work. Between 2003 and 2010, the lead author was employed by The Stop CFC in a variety of capacities, but is not currently an employee of the organization. challenges requires dynamic, multilevel and multisectoral strategies that integrate antipoverty efforts, ecological sustainability, food, wellness and community building throughout all aspects of the food system. Moving initiatives beyond the margins can begin by identifying and building on the successes of existing projects. In this pursuit, this paper articulates the case of The Stop Community Food Centre as it has evolved from a food bank offering emergency relief into a thriving neighborhood hub where people come together to grow, cook, and share food, and where people advocate for measures to establish a more just, sustainable, and healthy food system for all.

\section{Keywords}

antipoverty, community building, Community Food Centre, ecological sustainability, food and wellness, food bank, service hub, The Stop

\section{Introduction}

An increasing interest in food issues is evident from the expanding number and scope of 
individuals and organizations involved in food initiatives across North America (see for example Allen, 2004; Allen, Goodman, FitzSimmons, \& Warner, 2003; Canadian Cooperative Association [CCA], 2009; Elton, 2010; Katz, 2006; Kirbyson, 2005; Koc, MacRae, Mougeot, \& Welsh, 1999; Winne, 2010). These initiatives, while all involving food, are driven by a range of different goals, including social justice, ecological sustainability, health, and democratic decision-making. Critics have argued that many existing food-related initiatives tend toward a theoretical and practical separation of these goals (e.g., only ecological sustainability or only social justice) (Allen 2010; Allen, FitzSimmons, Goodman, \& Warner, 2003; Power, 1999). This is thought to limit the potential of this work to move beyond the margins of society and address long-term, structural challenges within the food system in an integrated and comprehensive way (Allen, 2004; Buttel, 1997; Johnston \& Baker, 2003).

Moving initiatives beyond the margins can begin with identifying and building on the successes of existing projects through sharing strategies (Diani \& Bison, 2004; Uvin \& Miller, 1996). This paper presents a case study of The Stop Community Food Centre (The Stop CFC), a nonprofit organization in Toronto, Canada, working to develop a comprehensive approach to addressing multiple challenges within the food system. A Community Food Centre (CFC) can be described as a neighborhoodbased, physical space that uses food as an entry point to promote the physical and emotional health of individuals and communities, and to develop community-based and state-level strategies to address challenges within the food system.

Following a brief account of our methods, the paper describes the evolution of The Stop CFC from a traditional food bank to a multiservice CFC. It documents how particular social and environmental goals - namely antipoverty, ecological sustainability, health and wellness, and communitybuilding - are incorporated into The Stop CFC s programming. The next section explores the particularly compelling aspects of the CFC approach, including its attempts to build social infrastructure by providing space for food-related activities and organizing, subsidizing a more equitable and sustainable food distribution system, developing a values-based practice, and directly engaging people in broader social, political, and ecological issues. The final section addresses some of the challenges and tensions faced by The Stop CFC. The paper concludes with a reflection on how the innovations and experiences of The Stop CFC can inform the broader food movement as it works towards a more sustainable, just, healthy, and democratic food system for all.

\section{Methods}

To document the evolution of The Stop CFC, an archival analysis of organizational materials was conducted. Materials reviewed included an annual survey of program participants, newsletters, websites, annual reports, and program evaluations. These materials were used to document the history of The Stop CFC, to identify the range of activities and programs undertaken by The Stop CFC, and to provide a sense of the scale and scope of each program.

This data was supplemented by informal interviews conducted by the principal author with senior level staff. These interviews were intended to enrich, clarify, and confirm the information drawn from the document analysis, rather than to draw out individual experiences with The Stop CFC.

These data were contextualized by the principal author's personal experience with the organization as a volunteer, staff member, and consultant between 2003 and 2010. While data is not presented explicitly from these experiences, the analysis and interpretation of the results are grounded in this extended period of engagement with the organization. As such, the paper is not intended as an solely as an "objective" or external assessment of The Stop CFC s work; rather, the paper provides an overview of The Stop $C F C$ and its work as seen by those who are intimately involved with it. At the same time, The Stop CFC is presented here not as a perfect case, but as a work in progress and as part of a broader food movement working toward a more sustainable food system for all. 


\section{The Evolution and Current Activities of The Stop Community Food Centre}

In the late 1970s, St. Stephen-in-the-Fields, a church in Toronto's downtown core, established a small food distribution project for those most affected by the growing recession in Canada. The initiative was developed in direct response to neighborhood residents living on low incomes who came knocking on the church's door, hungry and in increasing need (Russell, 2002). As that need increased, the emergency service operation quickly outgrew its original space, moved to a larger location, and incorporated as one of Canada's first food banks. Over time, the organization's leadership began to recognize the ineffectiveness of its short-term, charity-based solutions (Saul, 2002). The organization therefore began to incorporate political and social initiatives (for example, assisting people with landlord-tenant disputes, social services, and employment support) in addition to its emergency food program (Levkoe, 2004).

In 2001, the organization took the name The Stop Community Food Centre and moved to the Davenport West neighborhood (Saul, 2002), a community identified by Statistics Canada as one of the region's most diverse, but one with above-average rates of unemployment and low income (City of Toronto, 2006). The Stop CFCs food bank and drop-in meal programs adopted an emphasis on healthy food as a way to build morale and promote mental and physical health (The Stop, n.d. a). In 1998, the development of an urban agriculture program directly engaged The Stop CFC in issues of agroecological food production (Levkoe, 2006). Staff also began to recognize the impacts of building social ties and mutual support networks within communities. As resources increased, The Stop CFC was able to invest in a civic engagement process that supported community members in understanding and addressing root causes of poverty and food security (Levkoe, 2006).

Today, The Stop CFC maintains its emergency food programs in the form of a food bank and a drop-in food program, but has complemented these with a range of capacity-building, educational, and skills- training programs that include community kitchens, community gardens, and educational workshops that emphasize food-related skills and the reduction of social isolation, as well as civic engagement programs that involve program users in advocacy and community development initiatives (see table 1 on the following pages). In 2009, The Stop CFC launched the Green Barn (see figure 1) as a satellite sustainable food production and education center in partnership with Artscape, a local organization that specializes in the rehabilitation of underused buildings into community arts and culture venues. The Green Barn includes a stateof-the-art greenhouse, commercial kitchen, demonstration gardens, and classroom (Artscape, n.d.). In 2009, The Stop CFC had an operating budget of over CA $\$ 2.8$ million, the vast majority of which came from private donations (The Stop, 2009).

\section{Figure 1: The Stop CFC Green Barn}

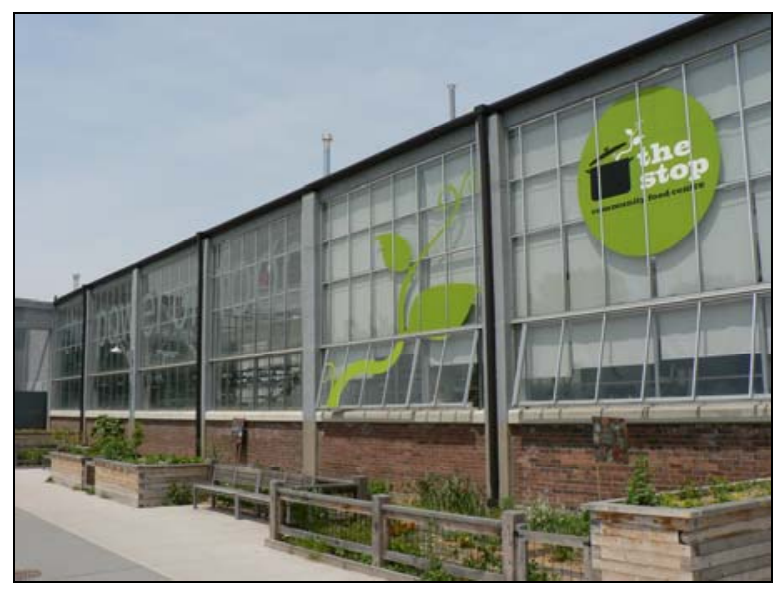

(Photo credit: Charles Z. Levkoe)

The following sections provide an overview of The Stop CFC s programming and activities, organized in relation to antipoverty, ecological sustainability, health and wellness, and community-building goals. The programs and their relationship to these goals are summarized in table 1, The Stop CFC program chart.

\section{Antipoverty Work}

The Stop CFC is rooted in low-income and immigrant communities, which have typically been left out of the food movement (Slocum, 2006). Most 


\section{Table 1. The Stop CFC Program Chart}

\begin{tabular}{|c|c|c|c|c|c|c|}
\hline Program* & Description* & Numbers $(2010)$ ** & Antipoverty Efforts & $\begin{array}{c}\text { Ecological } \\
\text { Sustainability }\end{array}$ & Food and Wellness & Community Building \\
\hline $\begin{array}{l}\text { Food Bank and Drop-in } \\
\text { Meal Program }\end{array}$ & $\begin{array}{l}\text { Access to a three-day } \\
\text { supply of food once a } \\
\text { month }\end{array}$ & $\begin{array}{l}\text { 13,038 food hampers } \\
\text { distributed; } \\
52,875 \text { meals served }\end{array}$ & $\begin{array}{l}\text { Meets immediate } \\
\text { food needs; offers } \\
\text { dignified environ- } \\
\text { ment; access to } \\
\text { information on } \\
\text { social issues, } \\
\text { housing, health } \\
\text { care, and welfare }\end{array}$ & $\begin{array}{l}\text { Availability of } \\
\text { sustainable, local } \\
\text { food }\end{array}$ & $\begin{array}{l}\text { Availability of high } \\
\text { quality, fresh food; } \\
\text { fosters social } \\
\text { connections }\end{array}$ & $\begin{array}{l}\text { Engages broad allies; } \\
\text { raises public } \\
\text { awareness }\end{array}$ \\
\hline Community Kitchens & $\begin{array}{l}\text { Participants cook and eat } \\
\text { together, learn and share } \\
\text { new skills }\end{array}$ & $\begin{array}{l}249 \text { community } \\
\text { kitchen sessions }\end{array}$ & $\begin{array}{l}\text { Meets immediate } \\
\text { food needs; offers } \\
\text { dignified environ- } \\
\text { ment }\end{array}$ & $\begin{array}{l}\text { Availability of } \\
\text { sustainable, local } \\
\text { food }\end{array}$ & $\begin{array}{l}\text { Availability of high } \\
\text { quality, fresh food; } \\
\text { fosters social } \\
\text { connections }\end{array}$ & $\begin{array}{l}\text { Builds knowledge and } \\
\text { skills; fosters } \\
\text { meaningful social } \\
\text { relationships }\end{array}$ \\
\hline $\begin{array}{l}\text { Healthy Beginnings } \\
\text { and Family Support }\end{array}$ & $\begin{array}{l}\text { Pre- and post-natal } \\
\text { nutrition and support } \\
\text { program for women living } \\
\text { on low incomes }\end{array}$ & $\begin{array}{l}261 \text { women took part, } \\
\text { for a total of } 2,464 \\
\text { visits }\end{array}$ & $\begin{array}{l}\text { Meets immediate } \\
\text { food needs; access } \\
\text { to information on } \\
\text { social issues, } \\
\text { housing, health } \\
\text { care, and welfare }\end{array}$ & $\begin{array}{l}\text { Availability of } \\
\text { sustainable, local } \\
\text { food }\end{array}$ & $\begin{array}{l}\text { Offers breast- } \\
\text { feeding support; } \\
\text { availability of high } \\
\text { quality, fresh food; } \\
\text { fosters social } \\
\text { connections }\end{array}$ & $\begin{array}{l}\text { Builds knowledge and } \\
\text { skills; fosters } \\
\text { meaningful social } \\
\text { relationships }\end{array}$ \\
\hline Community Action & $\begin{array}{l}\text { Support and training to } \\
\text { speak out about and work } \\
\text { together on issues of } \\
\text { poverty, hunger and } \\
\text { inadequate income }\end{array}$ & $\begin{array}{l}\text { 15,000 people } \\
\text { completed the Do the } \\
\text { Math online interactive } \\
\text { tool; } 1,000 \text { attended } \\
\text { film nights, antipoverty } \\
\text { rallies and Put Food in } \\
\text { the Budget events; } \\
1,623 \text { visits to the } \\
\text { community advocacy } \\
\text { office for referrals }\end{array}$ & $\begin{array}{l}\text { Promotes activism } \\
\text { and advocacy on } \\
\text { poverty issues }\end{array}$ & & $\begin{array}{l}\text { Fosters social } \\
\text { connections }\end{array}$ & $\begin{array}{l}\text { Builds knowledge and } \\
\text { skills; fosters } \\
\text { meaningful social } \\
\text { relationships; engages } \\
\text { broad allies; raises } \\
\text { public awareness }\end{array}$ \\
\hline
\end{tabular}




\begin{tabular}{|c|c|c|c|c|c|c|}
\hline Program* & Description* & Numbers $(2010) * *$ & Antipoverty Efforts & $\begin{array}{c}\text { Ecological } \\
\text { Sustainability }\end{array}$ & Food and Wellness & Community Building \\
\hline $\begin{array}{l}\text { Urban Agriculture } \\
\text { (greenhouse, } \\
\text { community gardens, } \\
\text { Yes In My Backyard, } \\
\text { Global Roots Garden, } \\
\text { compost systems) }\end{array}$ & $\begin{array}{l}\text { Multiple collectively } \\
\text { managed vegetable and } \\
\text { herb gardens along with a } \\
\text { garden share program } \\
\text { produce vegetables for } \\
\text { volunteers, the drop-in } \\
\text { meals and other programs }\end{array}$ & $\begin{array}{l}4,000 \mathrm{lbs} .(1,800 \mathrm{~kg}) \\
\text { of produce harvested } \\
\text { annually; } 249 \\
\text { sessions for adults in } \\
\text { the garden and } \\
\text { greenhouse; } 38,976 \\
\text { Ibs. }(17,679 \mathrm{~kg}) \text { of } \\
\text { waste composted at } \\
\text { the Green Barn }\end{array}$ & $\begin{array}{l}\text { Meets immediate } \\
\text { food needs }\end{array}$ & $\begin{array}{l}\text { Availability of } \\
\text { sustainable, local } \\
\text { food; production } \\
\text { using agro- } \\
\text { ecological } \\
\text { methods; } \\
\text { demonstrates } \\
\text { environmental } \\
\text { design; waste } \\
\text { diversion }\end{array}$ & $\begin{array}{l}\text { Availability of high } \\
\text { quality, fresh food; } \\
\text { fosters social } \\
\text { connections; } \\
\text { promotes physical } \\
\text { activity }\end{array}$ & $\begin{array}{l}\text { Builds knowledge and } \\
\text { skills; fosters } \\
\text { meaningful social } \\
\text { relationships; engages } \\
\text { broad allies; raises } \\
\text { public awareness }\end{array}$ \\
\hline $\begin{array}{l}\text { Bake Oven and } \\
\text { Markets } \\
\text { (Good Food Market, } \\
\text { farmers' market) }\end{array}$ & $\begin{array}{l}\text { A weekly affordable fresh } \\
\text { food market, seasonal } \\
\text { weekly pizza-baking } \\
\text { sessions at an outdoor } \\
\text { wood-fired bake oven, } \\
\text { and a year-round farmers' } \\
\text { market }\end{array}$ & $\begin{array}{l}39 \text { farmers sold } \\
\text { approximately CA } \$ 1 \\
\text { million at the farmers' } \\
\text { market; } 600 \text { people } \\
\text { shop at the farmers' } \\
\text { market, and between } \\
50 \text { and } 80 \text { shop at the } \\
\text { Good Food Market } \\
\text { weekly }\end{array}$ & $\begin{array}{l}\text { Meets immediate } \\
\text { food needs; offers } \\
\text { dignified } \\
\text { environment; } \\
\text { provides income } \\
\text { for farmers }\end{array}$ & $\begin{array}{l}\text { Availability of } \\
\text { sustainable, local } \\
\text { food }\end{array}$ & $\begin{array}{l}\text { Availability of high } \\
\text { quality, fresh food; } \\
\text { fosters social } \\
\text { connections }\end{array}$ & $\begin{array}{l}\text { Fosters meaningful } \\
\text { social relationships; } \\
\text { engages broad allies; } \\
\text { raises public } \\
\text { awareness }\end{array}$ \\
\hline $\begin{array}{l}\text { Sustainable Food } \\
\text { Systems Education }\end{array}$ & $\begin{array}{l}\text { Workshops for students } \\
\text { focused on food issues } \\
\text { that support the Ontario } \\
\text { curriculum, and an after- } \\
\text { school program for lower- } \\
\text { income kids providing } \\
\text { hands-on activities in the } \\
\text { kitchen, garden, and } \\
\text { greenhouse }\end{array}$ & $\begin{array}{l}365 \text { grade } 5 \text { children } \\
\text { spent } 4,600 \text { hours } \\
\text { studying food and } \\
\text { environmental } \\
\text { sustainability, social } \\
\text { justice, health and } \\
\text { diversity at the Green } \\
\text { Barn }\end{array}$ & $\begin{array}{l}\text { Meets immediate } \\
\text { food needs; pro- } \\
\text { motes activism } \\
\text { and advocacy on } \\
\text { poverty issues }\end{array}$ & $\begin{array}{l}\text { Availability of } \\
\text { sustainable, local } \\
\text { food; production } \\
\text { using agro- } \\
\text { ecological methods }\end{array}$ & $\begin{array}{l}\text { Availability of high } \\
\text { quality, fresh food; } \\
\text { fosters social } \\
\text { connections }\end{array}$ & $\begin{array}{l}\text { Builds knowledge and } \\
\text { skills; fosters } \\
\text { meaningful social } \\
\text { relationships; raises } \\
\text { public awareness }\end{array}$ \\
\hline Social Enterprise & $\begin{array}{l}\text { The Stop CFC's in-house } \\
\text { chefs host a variety of } \\
\text { initiatives aimed at raising } \\
\text { funds for front-line } \\
\text { programs including cater- } \\
\text { ing services, cooking } \\
\text { classes, dinners }\end{array}$ & & $\begin{array}{l}\text { Promotes activism } \\
\text { and advocacy on } \\
\text { poverty issues }\end{array}$ & $\begin{array}{l}\text { Availability of } \\
\text { sustainable, local } \\
\text { food }\end{array}$ & $\begin{array}{l}\text { Availability of high } \\
\text { quality, fresh food }\end{array}$ & $\begin{array}{l}\text { Engages broad allies; } \\
\text { raises public } \\
\text { awareness }\end{array}$ \\
\hline
\end{tabular}

* The Stop, n.d. b * The Stop, 2010; and Scharf et al., 2010 
people come to The Stop CFC because of the emergency services it offers - specifically, the food bank and the drop-in meal program (The Stop, 2010). While demand for these services has increased as a result of the latest economic downturn (Food Banks Canada, 2010), there has been significant criticism of emergency food programs. Food bank recipients report that these kinds of charity-based responses strip them of their dignity and do little to solve longer-term challenges (Hobbs, MacEachern, McIvor, \& Turner, 1993). Indeed, by providing a partial and short-term "solution" to the problem of hunger, some have argued that charitable emergency food programs prevent more fundamental systemic change (Allen, 1999; Poppendieck, 1998; Tarasuk \& Eakin, 2003).

While aware of these critiques, The Stop CFC continues to provide emergency food. Staff reported in interviews that they see this as justified and necessary given the demand for the programs and the absence of alternatives at the present time. However, The Stop CFC has attempted to respond to these concerns in a variety of ways. The aspects of emergency food programs that are considered by clients to be most degrading - such as long lineups, intrusive means testing, and lack of choice in food (Poppendieck, 1998) - have been eliminated. Instead, neighborhood residents using The Stop CFC s emergency services have access to renovated, comfortable waiting spaces, community information, beverages, and prepared foods. Further, staff reported in interviews that food bank users are not required to disclose personal information in order to participate and are able to select some specific items to include in their food hamper. Importantly, The Stop CFC has initiated two key advocacy efforts to increase incomes so that everyone can afford to buy healthy and sustainably produced food: "Do the Math" and "Put Food in the Budget" (eventually adopted by the Social Planning Network of Ontario) (Do the Math, n.d.; Put Food in the Budget [PFB], n.d.; Scharf, Levkoe, \& Saul, 2010). Both are intended to push for social assistance that ties welfare rates to an estimate of what it actually costs to live in Ontario. The Stop CFC is therefore not only distributing emergency food, but also struggling to publicize the links between growing poverty and insufficient access to acceptable food, and to push for policy-level solutions (Saul, 2010). In addition, while The Stop CFC s food bank and meal programs are primarily vehicles to distribute emergency food, they can serve as an entry point for neighborhood residents, who come to The Stop CFC initially for emergency food but subsequently become connected to other programming.

\section{Building Ecological Sustainability}

Ecological sustainability was distant from The Stop $C F C$ s original mandate, but over time it became increasingly difficult to ignore the environmental issues that arise in work around food (Levkoe, 2006). Today, The Stop CFCs community gardens (see figure 2) produce over 4,000 lbs. (1,800 kg) annually of fresh, organic produce, which is divided between programs and garden volunteers (The Stop, n.d. c). The backyard-sharing program "Yes in My Backyard (YIMBY)" connects city dwellers who have land to share with low-income people who want to garden but don't have access to space for growing food (see table 1). YIMBY offers workshops, tool sharing, and other opportunities for neighborhood residents to collaborate (The Stop, n.d. c). Both the community gardening and YIMBY programs are attempts to take advantage of available land and the investment of individual labor to make ecologically produced food available in the neighborhood to those who would have trouble affording it in stores.

\section{The Stop CFCs Gold LEED-certified Green Barn} (see figure 1) includes a greenhouse that grows organic produce year-round. Under the supervision of an experienced team of growers, children and adults gain hands-on experience in sustainable food production (The Stop, n.d. b). The produce grown is used for drop-in meals and other programs. The space also includes a sheltered garden used to demonstrate season-extension techniques for growing the diverse food plants of Toronto's multicultural communities. To complement community gardens growing produce, a series of large composting units and vermicomposting bins turn food waste into a growing medium for the gardens (The Stop, n.d. b) (see figure 3). Using 


\section{Figure 2: Community Gardens}

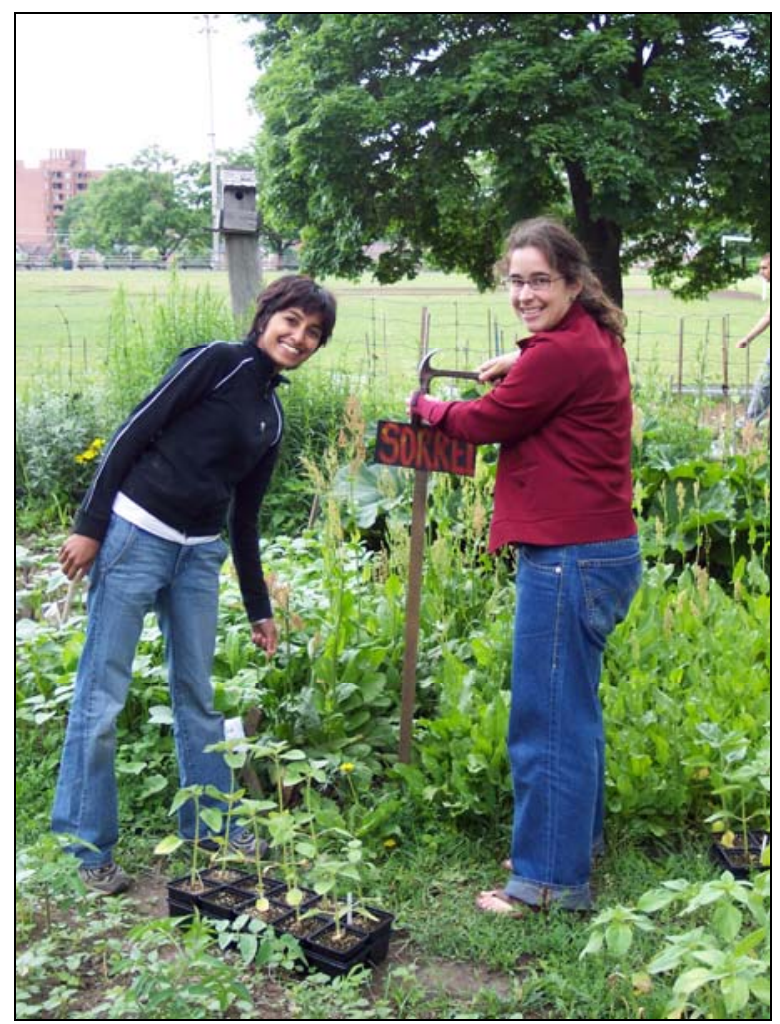

(Photo credit: Charles Z. Levkoe)

The Stop CFC s growing spaces, composting and food preparation initiatives (see table 1) for handson ecological education is considered foundational to The Stop CFC model (Scharf et al., 2010).

\section{Food and Wellness}

Providing fresh, nutritious, and delicious food is seen as central to The Stop CFC approach (The Stop, n.d. a). The Stop CFC has invested in healthy food by raising and targeting funds toward buying it, developing relationships with socially and ecologically conscious food suppliers to source it, and hiring trained, experienced, passionate chefs to prepare it (Scharf et al. 2010). Staff reported in interviews that The Stop CFC s drop-in meal program developed as a way to complement the food bank by providing food for people who do not have the ability to cook, to supplement their food access, and to provide a friendly, social space in a community with few public meeting places. Deciding to hire a professional chef to coordinate
Figure 3: Composting Bins

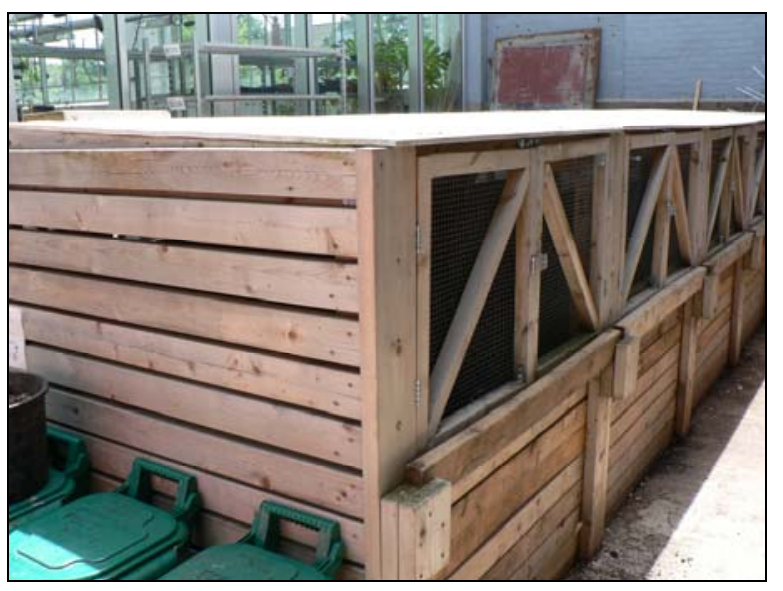

(Photo credit: Charles Z. Levkoe)

meal preparation has contributed to an increase in the quality of meals. Participants have reported that a good meal is important, not only for their physical health, but also for their emotional health and a sense of belonging (The Stop, 2010).

The Stop CFCs sooking and gardening programs seek to take advantage of the material, social, and emotional power of food. The literature suggests that knowing how to prepare and grow food can be a significant source of personal pride and selfesteem, and can give people the opportunity to participate in meaningful social relationships (Fano, Tyminski, \& Flynn, 2004). In 2010, 81\% of survey respondents in The Stop CFC s nonemergency programs said that their emotional health had improved through their involvement (The Stop, 2010). The Stop CFC s education programs target people across the lifecycle, from children (e.g., Sustainable Food Systems Education) and new mothers (e.g., Healthy Beginnings) to marginalized adults and seniors (e.g., Community Kitchens), with an objective to help them to reclaim these skills (see table 1 ).

The Stop CFC s community kitchens and gardens also offer opportunities for people to get their hands dirty and learn basic growing and cooking techniques (see figure 4). They aim to bring people together around food to promote physical activity and healthy eating (The Stop, n.d. b). A review of 
the literature about the impacts of community kitchens shows that they can have significant impacts on social supports and connectedness, as well as on personal health behaviors related to diet and nutrition (Engler-Stringer \& Berenbaum, 2005; Moldofsky, 2000; Tarasuk, 2001).

\section{Figure 4: Community Kitchens}

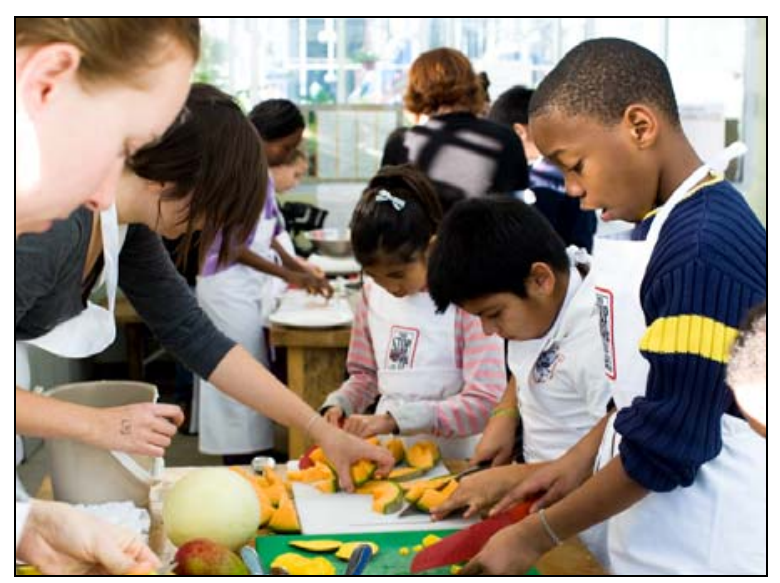

(Photo credit: Anna Prior)

Bringing people together to cook and garden has also revealed benefits ranging from informal and hands-on learning to positive social experiences and the development of mutual support networks. One of The Stop CFC s oldest programs, Healthy Beginnings (see table 1), offers a range of supports for pregnant women to encourage healthy nutrition as well as for new mothers and their children. These include workshops and referrals to ensure healthy birth outcomes and support for breastfeeding. This explicit emphasis on education, combined with practical material help, has yielded impressive results (with $98 \%$ healthy birth weights and over $90 \%$ of women breastfeeding) (The Stop, 2010).

The Stop CFC offers some food for purchase in addition to its emergency food programs. A weekly Good Food Market (see table 1) offers low-cost fresh produce sourced from The Ontario Food Terminal and increasingly from local organic farms. This program seeks to provide healthy food at a reasonable cost to a broader segment of the community.

\section{Developing Communities Through Food}

The Stop CFC has focused on increasing access to healthy food in ways that support nearby rural communities. For example, staff reported in interviews that a dedicated grant enables a monthly purchase for the food bank's "food of the month," usually an item of fresh produce, often organic and sourced from a local farmer. The Stop CFC has also developed a purchasing policy that gives priority to local products and fosters direct relationships with local farmers and with suppliers to purchase topquality food (without squeezing producers by suggesting they donate or sell produce at a low price). In 2010 alone, staff reported that The Stop CFC purchased approximately CA $\$ 70,000$ worth of local food $(22,000 \mathrm{lbs}$. $(9,980 \mathrm{~kg})$ - or CA $\$ 40,000$ worth — of which was local organic food) for its programs. These efforts recognize the community-strengthening potential of food procurement.

The Stop $C F C$ works to support program participants in building the skills and knowledge to actively participate in social change efforts in their community. After witnessing the diverse needs and assets of participants, The Stop CFCs staff realized that different types of participation opportunities needed to be created in order to match different levels of capacity to participate and employ assets possessed by community members. Beyond traditional volunteer opportunities, members can join the Community Action program, serve on advocacy committees (which offer a lower-commitment opportunity for involvement), or attend social and political film nights, where everyone is welcome and open conversation is encouraged (see figure 5). The Stop CFC staff uses honoraria, internships, and hiring of community members as a way to recognize and respect participants' dedication, commitment, and skills.

With growing popular interest in food issues, The Stop CFC has also identified an opportunity to engage people from higher income communities, thereby creating important allies in their work. To encourage this engagement, The Stop CFC has developed a range of programs geared at middleincome groups. For example, The Stop CFCs 


\section{Figure 5: Community Action Program}

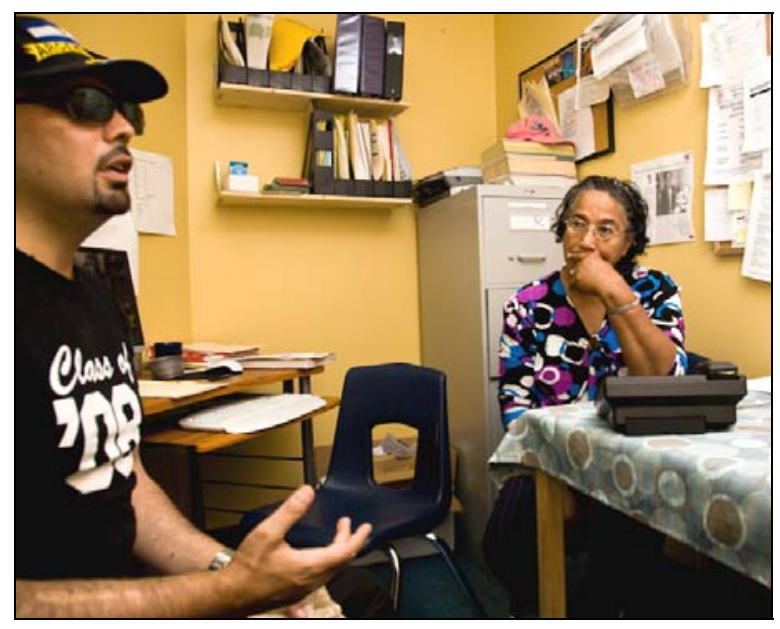

(Photo credit: Anna Prior)

Farmers' Market at the Green Barn is a largely organic market operated at a profit in a higherincome neighborhood (The Stop n.d. d). However, staff mentioned in interviews that The Stop CFC offers a food voucher program for volunteers; the vouchers can be redeemed for fresh produce at the Good Food Market. The objective is to increase access to fresh, healthy food for volunteers, reduce reliance on the food bank, and introduce the benefits of shopping at the Good Food Market to a broader range of consumers.

The Stop CFC has also taken an entrepreneurial approach to in-house events, cooking classes, catering, and other revenue-generating activities. These social enterprises have become a way of raising funds to support The Stop CFCs programming (The Stop n.d. h). However, The Stop $C F C$ organizers also see these types of activities as a way to raise broader public awareness about hunger and system sustainability issues by bringing in and educating different groups of people about food system issues and challenges. In this way, The Stop CFC uses food as a community development tool to support a broad range of community members to initiate social action processes.
The Stop CFC has also been a part of a number of regional networks such Sustain Ontario ${ }^{1}$ as a founding member, the Toronto Food Policy Council, ${ }^{2}$ and urban agriculture coalitions. This participation contributes to building a community of food practice where networks of individuals, organizations, and institutions can share knowledge and experiences related to the food system. By interacting with government bodies and organizations from multiple sectors, communities of practice offer a unique opportunity to learn from others, draw on and develop strategic resources, experiment with new project ideas, and collaborate on broader social change efforts (Friedmann, 2007).

\section{Bringing The Stop CFC to Other Communities}

In the fall of 2010, The Stop CFC began working on a process to replicate its CFC model. This involved securing and providing funding and strategic direction to groups in other regions wanting to establish a CFC to enhance their own work. To date, the replication process includes two pilot projects in Stratford and Perth, Ontario; a learning network to share resources on the core principles, program pillars, and evaluation, as well as regular networking events; and the early stages of a national organization to support the process.

Based on conversations with staff, it is clear that The Stop CFC recognizes that replication must go beyond simply sharing organizational program models. Its development and growth must be understood within a particular history, geography, and resource environment that may not be replicable elsewhere due to the finite nature of private funding sources and organizational capacity to pursue them. For example, The Stop CFC is

\footnotetext{
${ }^{1}$ Sustain Ontario: The Alliance for Healthy Food and Farming is a provincewide, cross-sectoral alliance that takes a collaborative approach to research, policy development, and action by addressing the intersecting issues related to healthy food and local sustainable agriculture. See http://www.sustainontario.com

2 The Toronto Food Policy Council is an instrument of local city government that works with all stakeholder groups to develop policies and programs promoting food security. See http://www.toronto.ca/health/tfpc index.htm
} 
located in a low-income neighborhood surrounded by higher-income communities, which provides access to a middle-class constituency that brings a level of financial resources, skills, and unscheduled time. Further, The Stop CFCs location in Toronto affords access to a large knowledge economy as well as financial and social resources to support non-profit organizations.

It should also be noted that The Stop CFC is the result of many hands - staff, participants, and board members - and of a particular historical time and place. In Toronto, the community of food practice, which includes other food-based organizations like FoodShare Toronto ${ }^{3}$ and the Toronto Food Policy Council, has made the city a vibrant incubator of food-based projects, and The Stop CFC has learned from, and contributed to, the new thinking emerging in this environment.

\section{The Community Food Centre Approach}

As the first CFC, The Stop CFC offers an important case study through which to explore progressive institutional responses to the problems of the mainstream food system. The innovation of the model and its contribution to the broader food movement is four-fold. First, The Stop CFC makes an explicit commitment to a broad set of core values: antipoverty, ecological sustainability, food and wellness, and community building. Organizers at The Stop CFC see this broadly integrative approach (in contrast to the more focused approach of many other organizations) as being central to addressing food system issues effectively.

Second, by providing a physical space in conjunction with knowledge and resources, the $\mathrm{CFC}$ aims to facilitate integrated programming that goes beyond service delivery. In essence, The Stop CFC provides "space" (both literally and figuratively) for food-related activities and organizing.

\footnotetext{
${ }^{3}$ FoodShare is a Toronto-based nonprofit organization that works on food issues "from field to table" and promotes healthy eating, teaches food preparation and cultivation, develops community capacity, and creates non-market-based forms of food distribution. See http://www.foodshare.net
}

Third, The Stop CFC subsidizes a more equitable and sustainable food distribution system through charitable donations and its own social enterprise efforts. That is, by applying its own resources (generated through donations, social enterprise activities, and volunteer labor), The Stop CFC is able to procure quality food at a cost that is manageable to program users, while providing sustainable livelihoods to program suppliers.

Finally, The Stop CFC works to directly engage people in the politics of their everyday lives by making connections from food to broader social, political, and ecological issues. The Stop CFC addresses the short-term, immediate needs of individuals needing food, but also attempts to build the infrastructure for people to contribute to longer-term social and ecological change. In the sections following, each of these points will be taken up in turn. The potential contributions of The Stop's CFC model will be explored and potential challenges discussed.

\section{Values-based Practice: Integrating Antipoverty, Ecological Sustainability, Food and Wellness, and Community-building $V$ alues}

As described in table 1, much of The Stop CFC's work incorporates antipoverty, ecological sustainability, food and wellness, and community-building values. More importantly, The Stop CFC has been actively working to develop a comprehensive approach that integrates these goals into all of its programming. The Stop CFCs mission, articulated on its website as "[striving] to increase access to healthy food in a manner that maintains dignity, builds community and challenges inequality" (The Stop, n.d. e) highlights the importance of health, community, and social justice. Food programs that address hunger simultaneously work to improve the health of participants and enhance the sustainability of local agriculture through purchasing decisions. Hands-on programs such as community gardens and food skills workshops address issues of food access and healthy living, and can be a first step in connecting and empowering participants. The Stop CFC s community action and advocacy efforts attempt to "directly address the root causes of poverty in our community" (The Stop, n.d. f), 
but also work toward changes in food and agricultural policy. The Stop CFC, for example, was one of the founding members of Sustain Ontario (a regional cross-sectoral food and farming alliance) and as a member of its steering committee has supported collaborative research, development, and action around policy.

It has been argued elsewhere (Levkoe, 2011) that keeping the values of social justice, ecological sustainability, and democratic decision-making at the forefront of food-related organizing and program development enhances the potential of these activities to contribute to a broader and more meaningful transformation of the food system. By acting on these values within one organization, The Stop CFC hopes to achieve fundamental change, both individually (in terms of changing the minds of program participants, volunteers, and others) and structurally (by transforming the food system).

\section{Building Social Infrastructure: \\ The Community Hub Model}

There is a strong place-based element to The Stop CFCs work. Having a physical space that thousands of people can walk into, where they can sit down for a meal, volunteer, cook, make a telephone call, or connect to community resources is essential. The Stop CFC is a community space where people can have conversations about food and food policy — be it with staff or with other community members.

As such, The Stop CFC is an early example of a community service hub. ${ }^{4}$ Two recent provincial reports, the Roots of Youth Violence Report (Curling \& McMurtry, 2008) and Ontario’s Poverty Reduction Strategy (Government of Ontario, 2009), both discuss the benefits of community hubs for moving beyond service delivery to providing spaces that facilitate connections between individuals and enable communities to become self-sufficient. Building on these reports

\footnotetext{
${ }^{4}$ A community service hub, as conceptualized here, should not be confused with a "food hub," which is generally conceived of as infrastructure to connect producers of locally grown food to nearby consumers.
}

and other literature, The Stop CFC can be conceptualized as a community hub with four main benefits. First, through a clustering of services, "hubs" can create synergies and efficiencies for service providers and for service users. In this "one-stop shop" model, users have access to a variety of human services in one location (or alternatively, an interlinked set of complementary services in adjacent locations). Research suggests that access to and awareness of community services are enhanced when services are integrated in a hub (Farrell, Tayler, \& Tennent, 2002). The benefits of accessing multiple services in one space can be illustrated by the following anecdote from a report about The Stop CFC:

When Robert first came to the drop-in meal program at The Stop, he was fighting mad. A former metalworker, he had suffered an injury that left him unable to work and struggling with chronic pain. He was losing his housing and had not been able to access disability benefits. What Stop staff saw at first was a man who started fights and spoke so abusively to the people who tried to help him that they wondered whether he should be barred from all but The Stop's emergency programs. The community advocacy coordinator decided to make a last-ditch effort to work with him to address his issues. With her help, he got medical care to manage his pain, secured disability benefits, and found stable housing. Eventually he expressed an interest in volunteering. The volunteer coordinator enlisted the community garden coordinator to put him to work in the garden, in what they hoped would be a soothing environment. Gardening struck a chord with him, and he became an enthusiastic participant in The Stop's gardening program, getting involved with an art project and dusting off some landscaping skills to help out relandscaping the front garden beds at The Stop. Inspired by The Stop's Yes in My Backyard project, Robert is now hoping to get his landlord's permission to transform his backyard into a vegetable garden that can be 
cultivated by someone without access to a garden. (Scharf et al., 2010, p. 8)

Second, locating numerous services in a single space or connected set of spaces enables staff to gain a better understanding of the needs and dynamics within the community. Beyond exposing residents to the range of services offered, staff and volunteers are able to see how the services interconnect and create mutual-support networks. As the anecdote above illustrates, contact with multiple staff — the community advocacy, volunteer, and garden coordinators - all contributed to building Robert's social support network. Other research has noted that the responsiveness of services is enhanced using a hub approach (Pascal, Bertram, Gasper, Mould, Ramsden, \& Saunders, 1999).

A third benefit is that the clustering of services in one location provides an opportunity to establish community space. By providing a physical space for neighborhood residents to meet, get to know each other and become engaged in their community, the CFC uses food to bring people together. Studies have shown that as social cohesion increases, mortality rates, suicide, and poor general and mental health decrease (Stafford et al., 2003). By connecting neighborhood residents to each other (as well as to volunteers and staff), The Stop CFC aims to enhance social cohesion.

Finally, community hubs provide the social infrastructure required for the effective use of community resources (Casey, 2005; Cowen \& Parlette, 2010; Eakin, 2004). The "hard" physical resources (e.g., meeting rooms, computer and Internet access, insurance coverage) as well as "soft" infrastructure (e.g., staff support for recruiting, training, and supervising volunteers) available at the CFC provide continuity across hub activities and over time. A number of studies over the last decade show a gain of between 2 and 11 dollars of public benefit and/or cost savings for every dollar invested in social infrastructure (Aos, Lieb, Mayfield, Miller, \& Pennucci, 2004; Karoly, Kilburn, Bigelow, Caulkins, Cannon, \& Chiesa, 2001; Karoly \& Bigelow, 2005).

\section{Subsidizing the Food System Through}

the Community Food Centre

The Stop CFC works to achieve its multiple goals by subsidizing food distribution through charitable donations and its own social enterprise efforts. That is, revenue generated in one area (fundraising and events including catering and dinners at the Green Barm) is used to support programs in other areas that would otherwise not be affordable to participants (either producers or consumers). By making food in some programs free or low-cost (i.e., by covering all or most of the costs associated with its production and distribution), this subsidy attempts to fill the gaps left by inadequate social programs, and helps develop accessible food distribution mechanisms that support local food economies. For example, interviews with staff revealed The Stop CFC uses donations to purchase sustainably produced food within adjacent agricultural regions, and to pay a fair price to farmers for that food. Similarly, volunteer labor (in place of paid labor) allows programs to run at lower cost to the organization. Ultimately, this subsidy is intended not only to provide immediate benefits to producers and consumers, but more importantly to begin to build the infrastructure (in food production and distribution) that can eventually serve as a model for a more substantive transformation of the existing (food) system.

The Stop CFC currently operates almost entirely on the basis of charitable donations, grants from foundations, and in-kind donations from individuals and organizations, with very little government support. The Stop CFC staff believes their work should be supported by the state. Conversations revealed that they recognize the limited and partial nature of the CFC's work, and continue to try to push this subsidy back into government hands - for example, through more adequate welfare provision, and through policies that would support local agriculture - through The Stop CFC s advocacy work. This has been the driving force behind the provincial Do the Math and Put Food in the Budget campaigns (see, for example, Saul, 2010). 


\section{Engaging People in the Food Movement}

By providing services that help to meet some of people's most pressing needs, The Stop CFC aims to open the door for people to participate in other programs that engage and support them in more profound ways. Once through the door, people have the chance to develop cooking or gardening skills, to connect to social services and to others in the community, or to contribute to broader movements for social change. In this way, The Stop CFC uses a therapeutic community development model (Bopp \& Bopp, 2001) to engage people at various stages in their personal development, and makes resources available to support them as individuals and for broader community development. Participants are given a number of opportunities to help shape the programs and services they use. For example, they are encouraged and given mechanisms to provide ongoing feedback to staff, participate in annual general meetings, and when able, return to The Stop $C F C$ as volunteers or paid interns. According to The Stop CFC website, involving program participants as volunteers and advocates "will end the way charity divides us as a society into the powerful and the powerless, the self-sufficient and the shamed" (The Stop, n.d. e).

Literature on participation suggests that for people to participate in broader social change efforts, engagement must feel safe and comfortable, and incorporate enjoyable social opportunities. It is also important to define intermediate advocacy goals that are satisfying and doable, so participants do not become disenchanted (Farmer \& Fedor, 1999; Mackenzie-Mohr, 2011). Through the civic engagement programs described above, The Stop CFC attempts to find appropriate ways for people with diverse needs and skills to be involved, while recognizing the limitations that poverty and marginalization can create. Staff report that, when dealing with marginalized community members, simply offering the opportunity for input, or handing over the responsibility for things such as meeting facilitation, event organizing, or advocacy campaigns, is unrealistic and ultimately frustrating for participants. Instead, through facilitation and support, experienced staff and volunteers attempt to create space for participants to make engagement with social issues possible and to understand what is achievable. For The Stop CFC, this approach has taken the form of supporting people materially to participate in decision-making (by providing food, transportation, honoraria, and child care) and offering educational opportunities to develop contextual knowledge and organizing skills.

\section{Challenges and Tensions: Navigating the Bumpy Terrain of Social Change}

The Stop CFC has had many successes over the past 30 years; however, this approach has not come without its challenges and is not a panacea. The nonprofit sector has been subject to many critiques, from serving to limit advocacy for social justice and broader social change (Ilcan \& Basok, 2004) to being complicit in neoliberal state restructuring (Mitchell, 2001). The Stop CFC is not immune to these critiques, and it has struggled to develop its model through a reflexive awareness of the challenges facing the broader sector. Recognizing these challenges and negotiating these tensions has been an important part of the development of The Stop CFC and is vital for the consideration of future implementation of this model.

One tension that has created challenges for The Stop CFC is associated with the nature of neighborhood-based interventions. Bringing services into the communities that need them most is commendable, but neighborhood-based initiatives (such as the CFC model presented here) have the potential to create disparities in overserviced and underserviced neighborhoods, particularly when hub development is associated with particular localized social service and/or charitable organizations rather than a broader and more systematic approach to identifying needs (Fyfe \& Milligan, 2003). In addition, initiatives provided through community service and charitable organizations typically have varying standards and expectations, in contrast to the universal standards of government welfare programs (Trudeau, 2008), although these admittedly have eroded. 
Over its history, The Stop CFC has attempted to align its operations with areas of need (for example, by choosing the site for its relocation into the Davenport neighborhood based in part on its socioeconomic characteristics), has developed a clear set of core principles and programming pillars that constitute the basis of the CFC (The Stop, n.d. $\mathrm{g}$ ), and has partnered with hundreds of stakeholders across the province (including Sustain Ontario and the Ontario Association of Food Banks) in order to better understand and navigate the needs and assets within the sector. However, given the multiple factors at play in the organization's decision-making (including revenue generation, site suitability and appropriate management of scarce resources), making decisions solely based on the "need" of local communities is not realistic. In addition, The Stop CFC as a single organization is not in a position to articulate - let alone provide - a uniform geography of food (and other) service provision that would meet the needs of city residents in any kind of systematic way.

There are examples of neighborhood-based organizations in other places attempting to overcome these challenges by working together to both standardize their offerings and provide comprehensive geographic coverage, to the extent that this is possible within their resources (see, for example, the work of the Emergency Food System Planning Team in the adjacent city of Hamilton (Emergency Food System Planning Team, 2009)). This kind of interorganizational cooperation could be a useful next step in the context of this case study, although the complexity and territoriality of the emergency food sector (and the charitable sector more generally — Lethabo-King \& Osayande, 2007; Milligan \& Fyfe, 2004) makes it a particularly challenging exercise. To date, this has not been identified as a priority of The Stop CFC.

This leads into what is perhaps the most fundamental challenge for CFC model: that the creation of service hubs organized by social service/ charitable organizations allows, and indeed may contribute to, the further erosion of the welfare state. As was discussed earlier in relation to food banks, the "taking over" of social service provision by charitable organizations (albeit in a fragmented and inconsistent way) allows governments to evade their responsibility to provide a minimum standard of welfare to their citizens through universal public programs (Wolch, 1989). At the same time, government (and to a certain extent, charitable foundation) funding of charitable organizations is seen to constrain the extent to which they can undertake radical social action (Smith, 2007).

The Stop CFC is a particularly interesting example here, as its lack of government funding demonstrates the organization's effective fundraising and social entrepreneurship (Ryzin, Grossman, DiPadova-Stocks, \& Bergrud, 2009). However, this is in practice neither an unmitigated blessing nor an unforgivable curse. Ultimately, part of The Stop CFC s success comes from being able to avoid the rigid constraints that come with government funding. That is, by avoiding state funding, The Stop CFC has also been able to avoid efforts to moderate or temper its activities. However, this self-sufficiency and lack of government involvement or regulation could be seen as contributing to the fragmentation and erosion of state-provided social services attendant in neoliberalism (see Hackworth, 2009). Leadership at The Stop CFC is well aware of this tension, and has attempted to find a balance between self-sufficiency (and the opportunities for self-determination that affords) and a role for government. Interestingly, a key component of the ongoing CFC replication process is an effort to build a case for government to play a major role in funding nascent CFCs. This, and The Stop CFC s ongoing advocacy efforts (which focus on re-involving the state in the provision of basic social services, particularly adequate welfare payments), point to an ongoing reflexivity about funding sources as well as an overarching attention to system-wide issues that is uncommon in both alternative food initiatives and the charitable sector more generally. At the same time, operationalizing the CFC model on a scale where a substantial shift in the status quo could be observed in relation to major food and other systemic issues such as hunger or environmental degradation is an enormous task. While replication of the CFC model is a current priority, The Stop 
CFC is only in a position to pilot two new CFCs over two years. The slow pace of change, the mismatch in the scale of problem and the CFC "solution," and the many challenges and tensions that need to be worked through as the projects move forward could lead observers to be skeptical of the radical potential of the CFC model. However, this skepticism is not a critique of the CFC model per se, but rather a recognition of the significance of the social change required. It is important that the recognition of the magnitude of these challenges not lead to paralysis, but rather to further and more widespread efforts to create change (Wakefield, 2007).

It should also be noted that The Stop CFC's engagement with certain aspects of (or perhaps more rightly, interpretations of) the key elements of a values-based practice as described earlier namely antipoverty, ecological sustainability, food and wellness, and community building — is not always as comprehensive in practice as might be hoped for in theory. By ensuring that the food available in its programs is healthy and as far as possible sustainably produced, by creating a welcoming, inclusive environment for program users and volunteers, and by encouraging more active engagement in the community and with social problems, The Stop CFC goes a long way toward providing a model for a more humane and sustainable food system. It does appear, however, that a somewhat selective interpretation of both social justice and democracy has informed its work. To be more specific, the focus on social justice articulated in its mission statement and elsewhere is often supplanted by a more narrow concern with the social welfare of the poor (i.e., antipoverty efforts). A concern with the humane treatment of those with fewer resources, and the important role of the state in providing that care, is laudable, and it should be noted that they have taken activism against poverty to heart, unlike many similar organizations. In addition, The Stop CFC has attempted to find ways to broaden its values-based practice to include local economic development (e.g., by purchasing food from local farms). However, this is not quite the same thing as a fundamental commitment to a fair and equitable food system, in which questions around, for example, the distribution of resources in society and the treatment of food workers might play a greater role. This is an area where the CFC model in future could direct more attention.

Similarly, The Stop CFC s commitment to involving members in shaping the organization - for example, through their involvement in annual general meetings, as staff, interns and/or volunteers, and by giving regular opportunities for feedback on programs - go beyond many similar organizations. In addition, its engaging of members and others in broader democratic systems through its advocacy campaigns indicates a significant commitment to political life. At the same time, the organization has struggled with ways to include members and volunteers throughout the governance structure of the organization. In the past, service users have served on The Stop CFC s board of directors, but their feedback revealed that the experience was often quite alienating. Failing to find ways to create participatory democratic structures within as well as external to the operations of The Stop CFC may be a missed opportunity. However, it is important to highlight how far The Stop CFC has come in both of these areas when compared to many other, similar organizations. This focuses attention on the broader structural challenges — including everything from the reluctance of funding agencies to support social justice oriented work (Lethabo-King \& Osayande, 2007) to the fundamental material inequalities and cultural biases that dictate opportunities for participation in civic life (Wakefield \& Poland, 2005) that must be overcome to create meaningful change in these areas.

The Stop CFC offers a vision and a structure that encompasses a set of basic principles that can be adapted to meet the specific needs of a particular community. However, this model should not be unreflexively copied within different contexts. Even in its current context, The Stop CFC is not without room for improvement, and the model should be opened to critical scrutiny and under- 
stood as only one part of the transition to a more socially just, ecologically sustainable, healthy and democratic food system. Replication should not be excessively prescriptive; instead, the constitution of each CFC needs to take into consideration the specific strengths, weaknesses, opportunities, and concerns of its geographical and historical context.

In order to create opportunities for future organizational learning and improvement, The Stop CFC has created its "learning network" as an interactive exchange of information and ideas. It is a place for The Stop CFC to share resources and information about the CFC model but also for others to engage in discussion about solutions to pressing food-related issues and provide ideas and feedback to The Stop CFC.

This effort highlights a key asset of The Stop CFC: an ability to be reflexive about its own activities and recognize and respond to criticism. Over time, the organization has taken to heart criticisms, for example, the undignified nature of food banks, and the ways that charity can undermine advocacy, and has done what it can to address them. These efforts have not always been fully successful, and are shaped by the same societal and structural constraints that The Stop CFC seeks to challenge. However, the organization explicitly acknowledges and struggles through these challenges; staff report that these issues are routinely included for discussion at training events. This willingness to listen and adapt is important in any organization that wants to create truly positive social change.

\section{Conclusion: Turning the Food Bank on its Head}

Taking into account the challenges articulated above, there is much to learn from the CFC model. The creation of spaces to support food-related activities is important not only as a platform for community development, but also as an incubator for practices and relationships that will be essential to any future sustainable, healthy, just, and democratic food system. By addressing a diversity of social and ecological goals, within programs as well as across the different activities of the organization, The Stop CFC is able to promote a more compre- hensive understanding of food system issues and their possible solutions than is often the case. And, by explicitly focusing on the power of food to engage and interest people in all walks of life, The Stop CFC is actively working to enhance understanding of food system issues and to encourage action to spur fundamental change in the food system that goes well beyond its own programs and activities.

It is important to recognize how The Stop CFC itself has been shaped by its context. In the same way that any future CFCs should be developed to take into consideration the specifics of local geographies and histories, The Stop CFC is itself a product of these factors. The Stop CFC is a creature of its environment, both practical and discursive; its activities have been supported and at the same time bounded by its funding sources, as well as by the understandings of its leaders, staff, board members, volunteers, and members. The evolution of The Stop CFC into an innovative and important actor within the regional, national, and potentially global food movement is due in part to its location in a city where considerable other related work is taking place (see Wekerle, 2004) and to its active participation in a community of food practice. The activities of other local organizations (e.g., FoodShare) and local government (particularly the formation of the Toronto Food Policy Council) have created fertile ground for the expansion of the organization in innovative ways. At the same time, broader societal pressures, such as the ongoing withdrawal of the state from social service provision, and the restructuring of the agricultural sector in ways that limit the ability of small farms to access the market cost-effectively, have shaped the organization's activities. Similarly, broader societal discourses have made particular framings of social justice more palatable than others, and this in turn shapes the practices of the organizations operating within these contexts.

It is important, then, not to position The Stop CFC as an "exceptional actor" that has managed to overcome all the constraints of its context to become an ideal model for future work. Instead, we conclude that what makes The Stop CFC an 
exciting model for food system transformation is the way that it has struggled, within a particular context, to work to transform the food system. With this in mind, the critiques raised, while important, should not be taken to imply that the success or failure of The Stop CFC is predetermined. Rather, they highlight the situatedness of The Stop CFC as an organization with both a history and a future, which connect in myriad ways to the history (and future) of the broader society from which it emerged. At the same time, one of the singular and important features of The Stop CFC is its reflexivity and ability to recognize and respond to the constraints of its setting. In the past, The Stop CFC has been transformed from an emergency food program (with all the attendant critiques) into a multifaceted CFC - and it is highly unlikely that this transformation is now somehow complete. In this context, the example of The Stop CFC can be understood as a work in progress, the success and struggles of which can inform the broader food movement as it works towards a more sustainable, just, healthy, and democratic food system for all.

\section{Acknowledgements}

The authors would like to acknowledge a grant from the Metcalf Foundation that supported the research for this paper and the initial report on which this article is based. We would also like to acknowledge the tireless efforts of Kathryn Scharf and Nick Saul for their work on the initial report, along with support from Elizabeth Fraser and all those at The Stop CFC whose determined work, words, and ideas made this paper possible. Thank you as well to the journal editor and the three anonymous reviewers for their helpful comments. The lead author gratefully acknowledges the financial support of a Social Sciences and Humanities Research Council of Canada Joseph-Armand Bombardier Canadian Graduate Scholarship Doctoral Award.

\section{References}

Allen, P. (1999). Reweaving the food security safety net: Mediating entitlement and entrepreneurship. Agriculture and Human Values, 16(2), 117-129. http://dx.doi.org/10.1023/A:1007593210496

Allen, P. (2004). Together at the table: Sustainability and sustenance in the American agrifood system. Philadelphia, Pennsylvania: Pennsylvania State University Press.

Allen, P. (2010). Realizing justice in local food systems. Cambridge Journal of Regions, Economy and Society, 3(2), 295-308. http://dx.doi.org/10.1093/cjres/rsq019

Allen, P., FitzSimmons, M., Goodman, M., \& Warner, K. (2003). Shifting plates in the agrifood landscape: The tectonics of alternative agrifood initiatives in California. Journal of Rural Studies, 19(1), 61-75. http://dx.doi.org/10.1016/S0743-0167(02) $\underline{00047-5}$

Allen, P., Goodman, M., FitzSimmons, M., \& Warner, K. (2003). Alternative food initiatives in California: Local efforts address systemic issues (Paper brief No. 4). Center for Agroecology and Sustainable Food Systems, University of California, Santa Cruz.

Aos, S., Lieb, R., Mayfield, J., Miller, M., \& Pennucci, A. (2004). Benefits and costs of prevention and early intervention programs for youth. Olympia, Washington: Washington State Institute for Public Policy.

Artscape. (n.d.). Components: Highlights of the Barns. Retrieved 21 November 2011 from http://www.torontoartscape.org/artscapewychwood-barns/project-highlights

Bopp M., \& Bopp, J. (2001). Recreating the world: A practical guide to building sustainable communities. Calgary: Four Worlds Press.

Buttel, F. (1997). Some observations on agrifood change and the future of agricultural sustainability movements. In D. Goodman \& M. Watts (Eds.), Globalizing food: Agrarian questions and global restructuring (344-365). New York: Routledge.

Casey, S. (2005). Establishing standards for social infrastructure. University of Queensland Boilerhouse Community Engagement Centre.

Canadian Cooperative Association (CCA). (2009). Lay of the land: Local food initiatives in Canada. Author. Retrieved 1 May 2011 from http://www.coopscanada.coop/public html/ assets/firefly/files/files/The_Lay_of_the_Land_ Final June 16 2009.pdf 
City of Toronto. (2006). City of Toronto Ward 17

Davenport Profile. Retrieved on 1 December 2010 from http://www.toronto.ca/wards2000/ ward17.htm

Cowen, D., \& Parlette, V. (2010). Social infrastructure in the inner suburbs: Poverty and the Priority Neighbourhoods Strategy in East Scarborough (unpublished report). Department of Geography and Programme in Planning, University of Toronto.

Curling, A., \& McMurtry, R. (2008). The Third Pillar: Building Strong Communities to Address the Roots of Violence Involving Youth (Chapter 9). Findings, analysis and conclusions (volume 1), Roots of Youth Violence Report. Ontario Ministry of Children and Youth Services. Retrieved from http://www.rootsofyouthviolence.on.ca

Diani, M., \& Bison, I. (2004). Organizations, coalitions and movements. Theory and Society, 33(3-4), 281309. http://dx.doi.org/10.1023/ B:RYSO.0000038610.00045.07

Do The Math. (n.d.). Do The Math website. Retrieved 1 May 2011 from http://dothemath.thestop.org

Eakin, L. (2004, May). Community capacity draining: The impact of current funding practices on non-profit community organizations. Community Social Planning Council of Toronto in collaboration with the City Community Workgroup on Core Funding. Retrieved from http://neighbourhoodcentres.ca/ reportspub/Community $\% 20$ Capacity $\% 20$ Draining \%20Report.pdf

Elton, S. (2010). Locavore: From farmers' fields to rooftop gardens: How Canadians are changing the way we eat. Toronto: Harper Collins.

Emergency Food System Planning Team. (2009). No one goes hungry: Strategic directions for Hamilton's Emergency. Food System Plan 2010-2012. City of Hamilton, Ontario. Retrieved from http://www.hamilton.ca/ NR/rdonlyres/1A6083FA-63B1-4024-AC35A429A20DBFA7/0/Nov18Item75CS09072REPO RTEmergencyFoodSystemPlanFINAL21.pdf

Engler-Stringer, R., \& Berenbaum, S. (2005). Collective kitchens in Canada: A review of the literature. Canadian Journal of Dietetic Practice and Research, 66(4), 246-251. http://dx.doi.org/10.3148/66.4.2005.246

Fano, T. J., Tyminski, S. M., \& Flynn, M. A. T. (2004). Evaluation of a collective kitchens program: Using the population health model. Canadian Journal of Dietetic Practice and Research, 65(2), 72-80. http://dx.doi.org/10.3148/65.2.2004.72
Farmer, S. M., \& Fedor, D. B. (1999). Volunteer participation and withdrawal. Nonprofit Management and Leadership, 9(4), 349-368. http://dx.doi.org/10.1002/nml.9402

Farrell, A., Tayler, C. P., \& Tennent, L. (2002, April). Community hubs: Their potential to enhance social capital and service provision for families and young children. Presentation at the World Forum Conference, Auckland, New Zealand. Retrieved from http://eprints.qut.edu.au/292/

Food Banks Canada. (2010). HungerCount 2010: A comprehensive report on hunger and food bank use in Canada. Toronto, Ontario: Author. Retrieved from http://www.foodbankscanada.ca

Friedmann, H. (2007). Scaling up: Bringing public institutions and food service corporations into the project for a local, sustainable food system in Ontario. Agriculture and Human V alues, 24(3), 389398. http://dx.doi.org/10.1007/s10460-006-9040-2

Fyfe, N., \& Milligan, C. (2003). Space, citizenship, and voluntarism: Critical reflections on the voluntary welfare sector in Glasgow. Environment and Planning A, 35(11), 2069-2086. http://dx.doi.org/10.1068/ $\underline{\mathrm{a} 35306}$

Government of Ontario. (2009). Stronger, healthier communities (Chapter 2). Breaking the Cycle: Ontario's Poverty Reduction Strategy. Retrieved from http://www.Ontario.ca/breakingthecycle

Hackworth, J. (2009). Neoliberalism, partiality, and the politics of faith-based welfare in the United States. Studies in Political Economy, 84, 155-179.

Hobbs, K., MacEachern, W., McIvor, A., \& Turner, S. (1993). Waste of a nation: Poor people speak out about charity. The Canadian Review of Social Policy, 31, 94-104.

Ilcan, S., \& Basok, T. (2004). Community government: Voluntary agencies, social justice, and the responsibilization of citizens. Citizenship Studies, 8(2), 129-144. http://dx.doi.org/10.1080/ 1362102042000214714

Johnston, J., \& Baker, L. (2003). Eating outside the box: FoodShare's good food box and the challenges of scale. Agriculture Food and Human V alues, 22, 313325. http://dx.doi.org/10.1007/s10460-005-6048-y

Karoly, L., \& Bigelow, J. (2005). The economics of investing in universal pre-school education in California. Santa Monica, California: The Rand Corporation. 
Karoly, L., Kilburn, M., Bigelow, J., Caulkins, J., Cannon, J., \& Chiesa, J. (2001). Assessing the costs and benefits of early childhood intervention programs. Santa Monica, California: The Rand Corporation.

Katz, S. E. (2006). Revolution will not be microwaved: Inside America's underground food movement. White River Junction, Vermont: Chelsea Green.

Kirbyson, A. M. (Ed.). (2005). Recipes for success: $A$ celebration of food security work in Canada. Chicago, Illinois: Independent Publishers Group.

Koc, M., MacRae, R., Mougeot, L., \& Welsh, J. (Eds.). (1999). For hunger-proof cities: Sustainable urban food systems. Ottawa, Canada: International Development Research Centre.

Lethabo-King, T., \& Osayande, E. (2007). The filth on philanthropy. In Incite! Women of Colour Against Violence (Ed.), The revolution will not be funded. Cambridge, Massachusetts: South End Press.

Levkoe, C. (2011). Towards a transformative food politics. Local Environment, 16(7): 687-705. http://dx.doi.org/10.1080/13549839.2011.592182

Levkoe, C. (2006). Learning democracy through food justice movements. Agriculture and Human Values, 23(1), 89-98. http://dx.doi.org/10.1007/s10460005-5871-5

Levkoe, C. (2004). Widening the approach to food insecurity: The Stop Community Food Centre. The Canadian Review of Social Policy, 52, 128-132.

Mackenzie-Mohr, D. (2011). Fostering sustainable behavior (third edition). Gabriola Island, British Columbia: New Society Publishers.

Milligan, C., \& Fyfe, N. (2004). Putting the voluntary sector in its place: Geographical perspectives on voluntary activity and social welfare in Glasgow. Journal of Social Policy, 33(1), 73-93. http://dx.doi.org/10.1017/S0047279403007268

Mitchell, K. (2001). Transnationalism, neo-liberalism, and the rise of the shadow state. Economy and Society, 30(2), 165-189. http://dx.doi.org/10.1080/ $\underline{03085140120042262}$

Moldofsky, Z. (2000). Meals made easy: A group program at a food bank. Social Work with Groups, 23(1), 83-96. http://dx.doi.org/10.1300/ I009v23n01 06

Pascal, C., Bertram, T., Gasper, M., Mould, C., Ramsden, F., \& Saunders, M. (1999, July). Research to inform the Early Excellence Centre's pilot program. Worcester, UK: Centre for Research in Early Childhood.
Poppendieck, J. (1998). Sweet charity: Emergency food and the end of entitlement. New York, New York: Penguin.

Power, E. (1999). Combining social justice and sustainability for food security. In M. Koc, R. MacRae, L. Mougeot, and J. Welsh (Eds.), For Hunger-Proof Cities (pp. 30-37). Ottawa: International Development Research Centre.

Put Food in the Budget [PFB]. (n.d.). About Put Food in the Budget]. Retrieved 21 November 2011 from http://povertywatchontario.ca/put-food-in-thebudget/

Russell, C. (2002, Fall). In the beginning. The Stop News, 2.

Ryzin, G., Grossman, S., DiPadova-Stocks, L., \& Bergrud, E. (2009). Portrait of the social entrepreneur: Statistical evidence from a US panel. Voluntas, 20(2), 129-140. http://dx.doi.org/ 10.1007/s11266-009-9081-4

Saul, N. (2010, April 10). Reality of living on social assistance. The Toronto Star. Retrieved 1 May 2011 from http://www.thestar.com/opinion/article/ 790638--reality-of-living-on-social-assistance

Saul, N. (2002, Fall). The name gain. The Stop News, 1.

Scharf, K., Levkoe, C., \& Saul, N. (2010). In every community a place for food: The role of the Community Food Centre in building a local, sustainable and just food system. Metcalf Food Solutions Paper. Retrieved 1 October 2011 from http://www.metcalffoundation.com

Slocum, R. (2006). Anti-racist practice and the work of community food organizations. Antipode, 38(2), 327-349. http://dx.doi.org/10.1111/j.1467$\underline{8330.2006 .00582 . x}$

Smith, A. (2007). Introduction. In Incite! Women of Colour Against Violence (Ed.), The revolution will not be funded. Cambridge, Massachusetts: South End Press.

Stafford, M., Bartley, M., Sacker, A., Marmot, M., Wilkinson, R., Boreham, R., \& Thomas, R. (2003). Measuring the social environment: Social cohesion and material deprivation in English and Scottish neighbourhoods. Environment and Planning A, 35(8), 1459-1475. http://dx.doi.org/10.1068/a35257

Tarasuk, V. (2001). A critical examination of community-based responses to household food insecurity in Canada. Health Education \& Behavior, 28(4), 487-499. http://dx.doi.org/10.1177/ $\underline{109019810102800408}$ 
Tarasuk, V., \& Eakin, J. (2003). Charitable food assistance as a symbolic gesture: An ethnographic study of food banks in Ontario. Social Science and Medicine, 56(7), 1505-1515. http://dx.doi.org/ 10.1016/S0277-9536(02)00152-1

The Stop Community Food Centre (The Stop). (2010). The Stop By The Numbers 2009/2010. Annual Survey. The Stop Community Food Centre, Toronto, Ontario.

The Stop. (2009, August 31). Audited annual financial statements The Stop Community Food Centre, Toronto, Ontario.

The Stop. (n.d. a). The Stop's Healthy Food Philosophy. Retrieved 21 May 2011 from http://www.thestop. org/community-food-centre-model

The Stop. (n.d. b). The Stop Community Food Centre's Programs. Retrieved 21 May 2011 from http://www.thestop.org/community-food-centremodel

The Stop. (n.d. c). Urban Agriculture. Retrieved 21 May 2011 from http://www.thestop.org/communitygardens

The Stop. (n.d. d). Food Markets and Bake Oven. Retrieved 21 May 2011 from http://www.thestop.org/bakeovens-markets

The Stop. (n.d. e). Mission. Retrieved 21 May 2011 from http://www.thestop.org/mission

The Stop. (n.d. f). Community Action. Retrieved 21 May 2011 from http://thestop.org/community-action

The Stop. (n.d. g). What is a Community Food Centre? Retrieved 21 May 2011 from http://www.thestop. org/community-food-centre-model

The Stop CFC. (n.d. h). Catering. Retrieved 21 May 2011 from http://www.thestop.org/catering
Trudeau, D., (2008). Junior partner or empowered community? The role of non-profit social service providers amidst state restructuring in the US. Urban Studies, 45(13), 2805-2827. http://dx.doi.org/10.1177/0042098008098207

Uvin, P., \& Miller, D. (1996). Paths to scaling-up: Alternative strategies for local nongovernmental organizations. Human Organization, 55(3), 344-354. Available at http://sfaa.metapress.com/openurl. asp?genre $=$ article\&eissn $=1938-3525 \&$ volume $=$ 55\&issue $=3 \&$ spage $=344$

Wakefield, S. (2007). Reflective action in the academy: Exploring praxis in critical geography using a "food movement” case study. Antipode, 39(2), 331-354. http://dx.doi.org/10.1111/j.14678330.2007.00524.x

Wakefield, S., \& Poland, B. (2005). "Family, friend or foe?" Critical reflections on the relevance and role of social capital in health promotion and community development. Social Science and Medicine, 60(12), 2819-2832. http://dx.doi.org/10.1016/ j.socscimed.2004.11.012

Wekerle, G. (2004). Food justice movements: Policy, planning and networks. Journal of Planning Education and Research, 23(4), 378-386. http://dx.doi.org/ $\underline{10.1177 / 0739456 X 04264886}$

Winne, M. (2010). Food rebels, guerrilla gardeners, and smartcookin' mamas: Fighting back in an age of industrial agriculture. Boston, Massachusetts: Beacon Press.

Wolch, J. R. (1989). The shadow state: Transformations in the voluntary sector. In J. Wolch \& M. Dear (Eds.), The Power of Geography: How Territory Shapes Social Life (197-221). Boston, Massachusetts: Unwin Hyman. 